\title{
Diagnostic Approach and Management of a Unilateral Total Ectopy of the Scrotum
}

\section{Kimassoum Rimtebaye1, Choua Ouchemi'1, Arya Zarif Agah Tashkand1, Franklin Danki Sillong2, Edouard Hervé Moby Mpah³, Mignagnal Kaboro', Lamine Niang4, Serigne Magueye Gueye ${ }^{4}$}

\author{
${ }^{1}$ General Referal National Hospital of N'Djamena, N'Djamena, Chad \\ ${ }^{2}$ Protestant Hospital of N'Gaoundere, N'Gaoundere, Cameroon \\ ${ }^{3}$ Laquintinie Hospital of Douala, Douala, Cameroon \\ 4"Grand Yoff”, General Hospital of Dakar, Dakar, Senegal \\ Email: *melinarim@yahoo.fr
}

How to cite this paper: Rimtebaye, $\mathrm{K}$. Ouchemi, C., Tashkand, A.Z.A., Sillong, F.D., Mpah, E.H.M., Kaboro, M., Niang, L. and Gueye, S.M. (2017) Diagnostic Approach and Management of a Unilateral Total Ectopy of the Scrotum. Open Journal of Urology, 7, 139. 145 .

https://doi.org/10.4236/oju.2017.79017

Received: June 5, 2017

Accepted: August 18, 2017

Published: August 21, 2017

Copyright (C) 2017 by authors and Scientific Research Publishing Inc. This work is licensed under the Creative Commons Attribution International License (CC BY 4.0).

http://creativecommons.org/licenses/by/4.0/

\begin{abstract}
Introduction: Total unilateral ectopy of the scrotum can be defined by the abnormal congenital anatomical position of the scrotum and its contents. The aim of the study is to describe the diagnostic and therapeutic approach of a total unilateral ectopy of the right scrotum. Methods: This is a clinical observation of a 46-year-old patient with a right abdominal mass evolving from birth. Analyzing the cluster of arguments clinically, operatively and anatomopathologically, allowed us to retain the diagnosis of a total unilateral ectopy of the right scrotum. The informed consent of the patient was obtained before the use of the images for scientific purposes. Conclusion: the unilateral total ectopy of the right scrotum is a rare congenital malformation of the external genitalia, which clinical diagnosis is difficult. Its management is surgical.
\end{abstract}

\section{Keywords}

Testicular Ectopy, Scrotum, Medial Raphe, Orchidopexia, Gubernaculum

\section{Introduction}

The scrotum is an even organ, normally located below the penis and the anterior part of the perineum [1] [2]. Any anatomical position, of the scrotum and its contents apart from that mentioned above, defines the total ectopy of the scrotum. This definition excludes penoscrotal transposition and testicular ectopy [3] [4], which are the well-known malformation pathologies of external genitalia. The median raphe delimits the border between the right and the left scrotum. Unilateral total ectopy of the right scrotum is a rare congenital malformation whose etio physiopathology remains to be determined. Its treatment is surgical. The 
purpose of this study is to describe the diagnostic procedure and the management of a total unilateral ectopy of the right scrotum, based on a clinical observation.

\section{Observation}

Mr XY, 46 years old, monogamous, with 8 children, 6 of whom are in live, had consulted for a swelling sitting on the right flank and right inguinal region [Figure 1] standing on the right wing of the pubis. The patient reported that this mass had existed since birth and was painless. However, in recent months, it has been necessary to increase the amount of money available. On physical examination, the hemodynamic constants were normal; the general condition was well preserved. The right abdomino-pelvic region was a painless, irreducible, coughexpansive, rolling under the hand, finely pleated with elasticity, but without hairiness [Figure 2]. The examination of the external genitalia was carried out in the absence of the ipsilateral testicle to the right abdomino-pelvic mass but, the presence of the left testicular in normal position. Unusually, the absence of the median raphe normally delineates the boundary between the right and the left [Figure 3]. At the end of the physical examination, blood grouping, blood glucose, serum creatinine, spermogram and abdomino-pelvic ultrasound were performed. The result of the blood test was normal as well as the spermogram. The ultrasound concluded with an abdominal hernia without more information.

After informed consent of the patient, a surgical exploration was decided and executed. The surgical procedure was performed under general anesthesia with orotracheal intubation. It has been allowed to individualize: a hernia, to the article of normal size and consistency to the skin by a ligament [Figure 4]. Firstly,

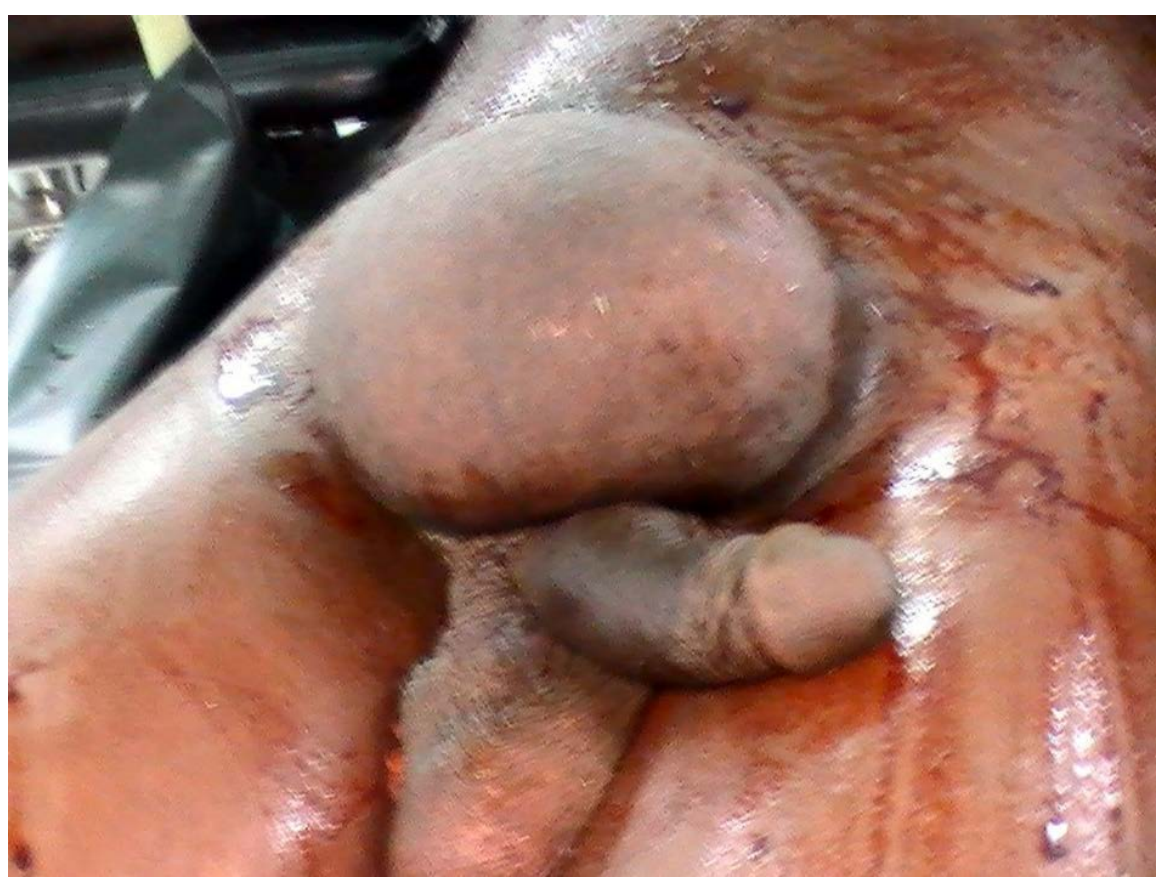

Figure 1. Right abdomino-pelvic mass. 


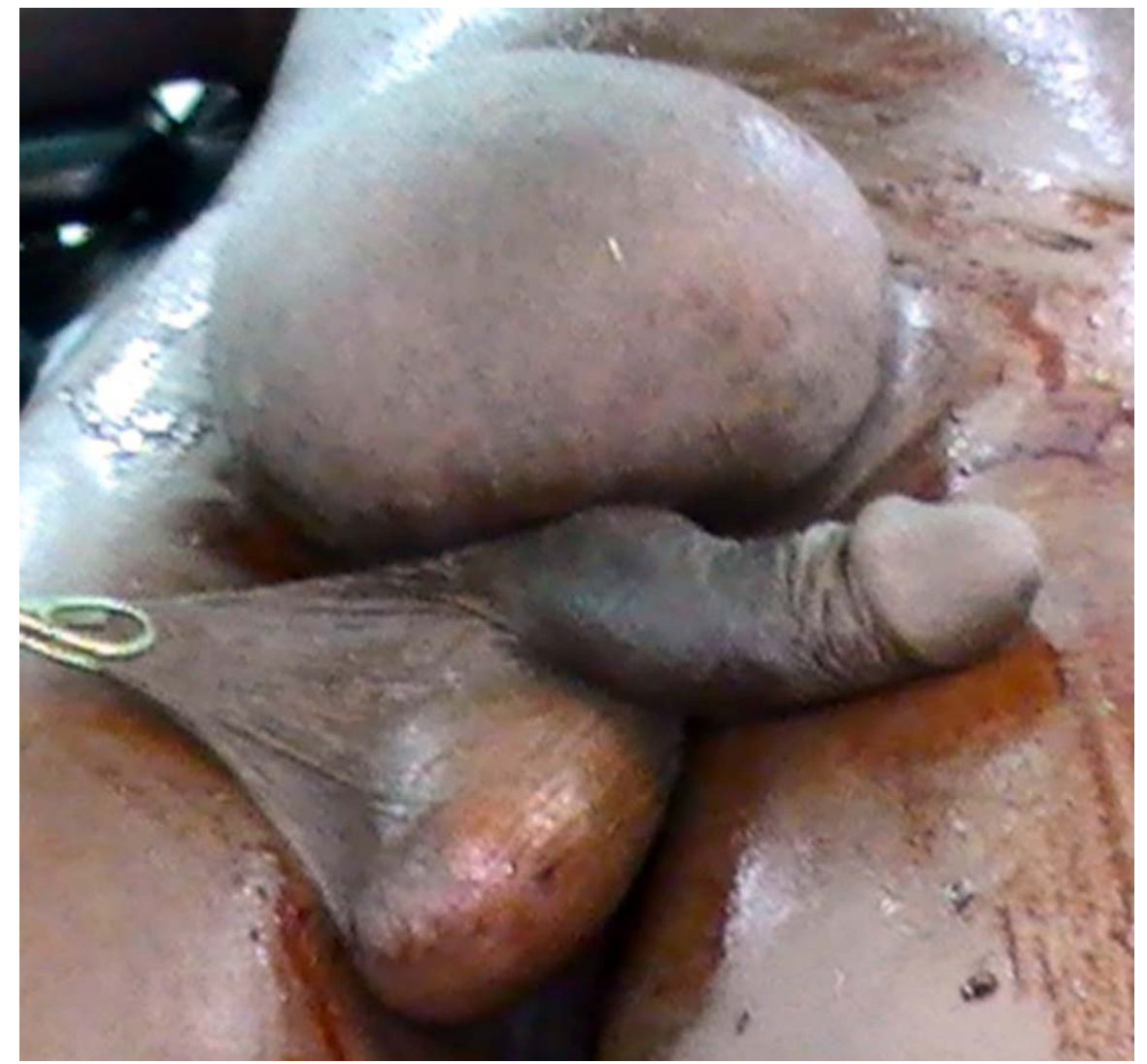

Figure 2. Absence of the median raphe.

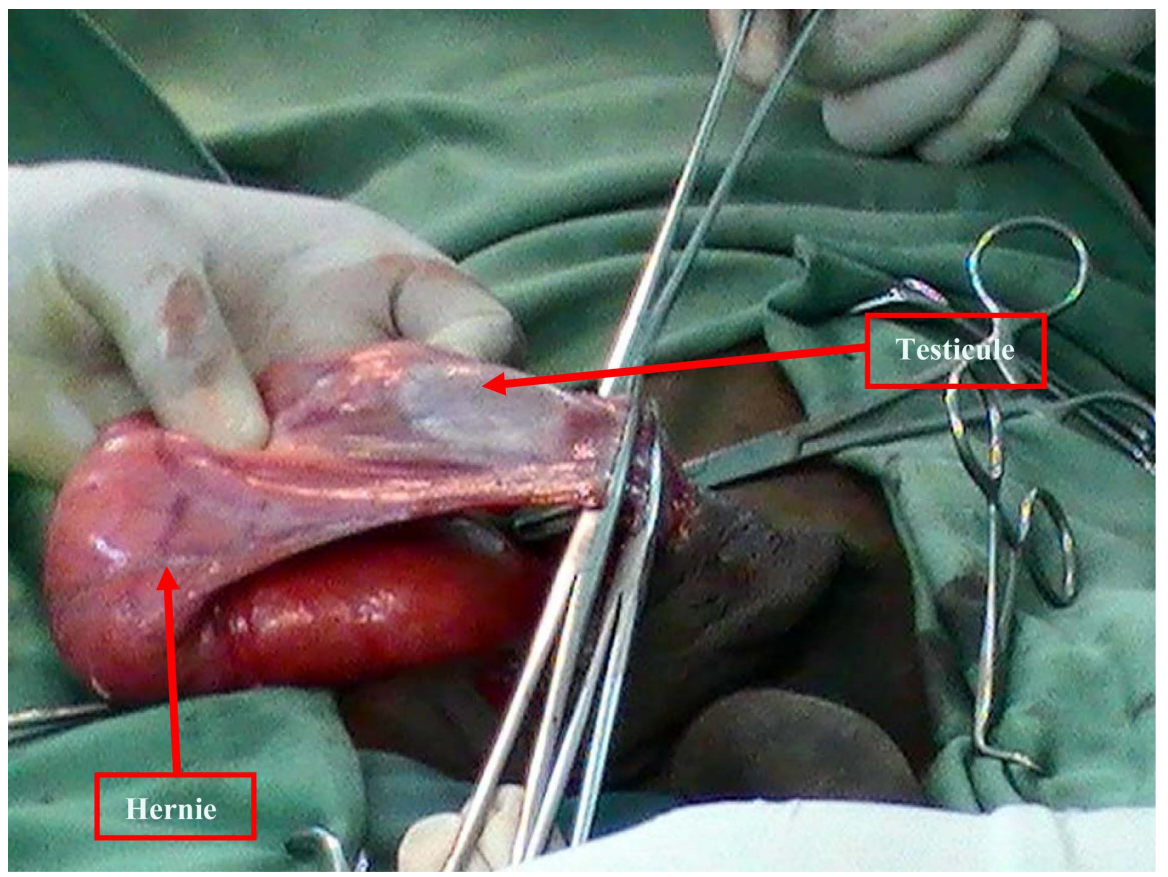

Figure 3. Ectopic testicle of normal size and consistency.

we choose to reduce the hernia and close the collar. Secondly, we had cut the suspensory ligament (gubernaculum testis) and proceeded with the "skeletonization" 


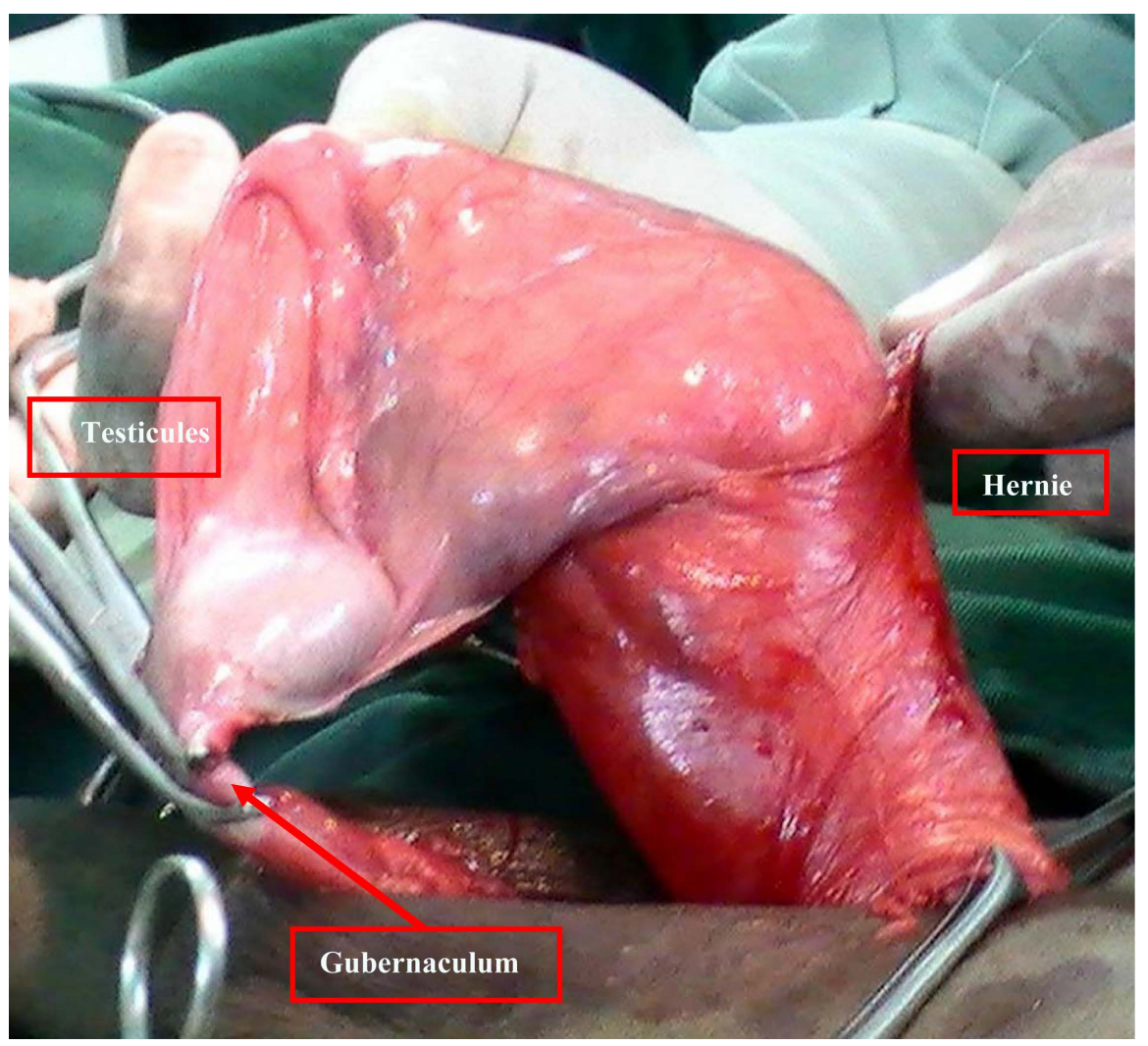

Figure 4. Individualization of the gubernaculums.

of the cord allowing to obtain a length judged sufficient in anticipation of an orchidopexy. In a third step, we proceeded to a digital drilling of a subcutaneous tunnel from the lower angle of the abdominal cut to the left scrotum. Through a cutaneous incision of the envelopes of the left scrotum we introduced a clamp of Bengolea which came to catch the ectopic testicle and proceed to an orchidopexy in the left scrotum. The excess skin of the right abdomino-pelvic was excised and the piece addressed for pathological analysis. The histological analysis confirmed that it was a scrotal skin with its different envelopes. The results were simple with a functional result (normal spermogram, normal coitus, and a satisfactory aesthetic [Figure 5] with a three-year follow-up. The informed consent of the patient was obtained before the use of the images for scientific purposes.

\section{Discussion}

\subsection{Embryologique Recall}

Sexual differentiation begins from the end of the fourth week of intrauterine life. The SRY [5] gene carried by the short arm of the Y chromosome induces the development towards the male sex of a gonad that was undifferentiated until the fourth week of intrauterine life. Two structures will participate in the formation of the gonads: the coelomic epithelium and the subcoelomic mesenchyme, these are primary cellular cords. The presence of the SRY gene leads to the differentiation of the gonad to the testis. The testicular embryological secretion allows the 


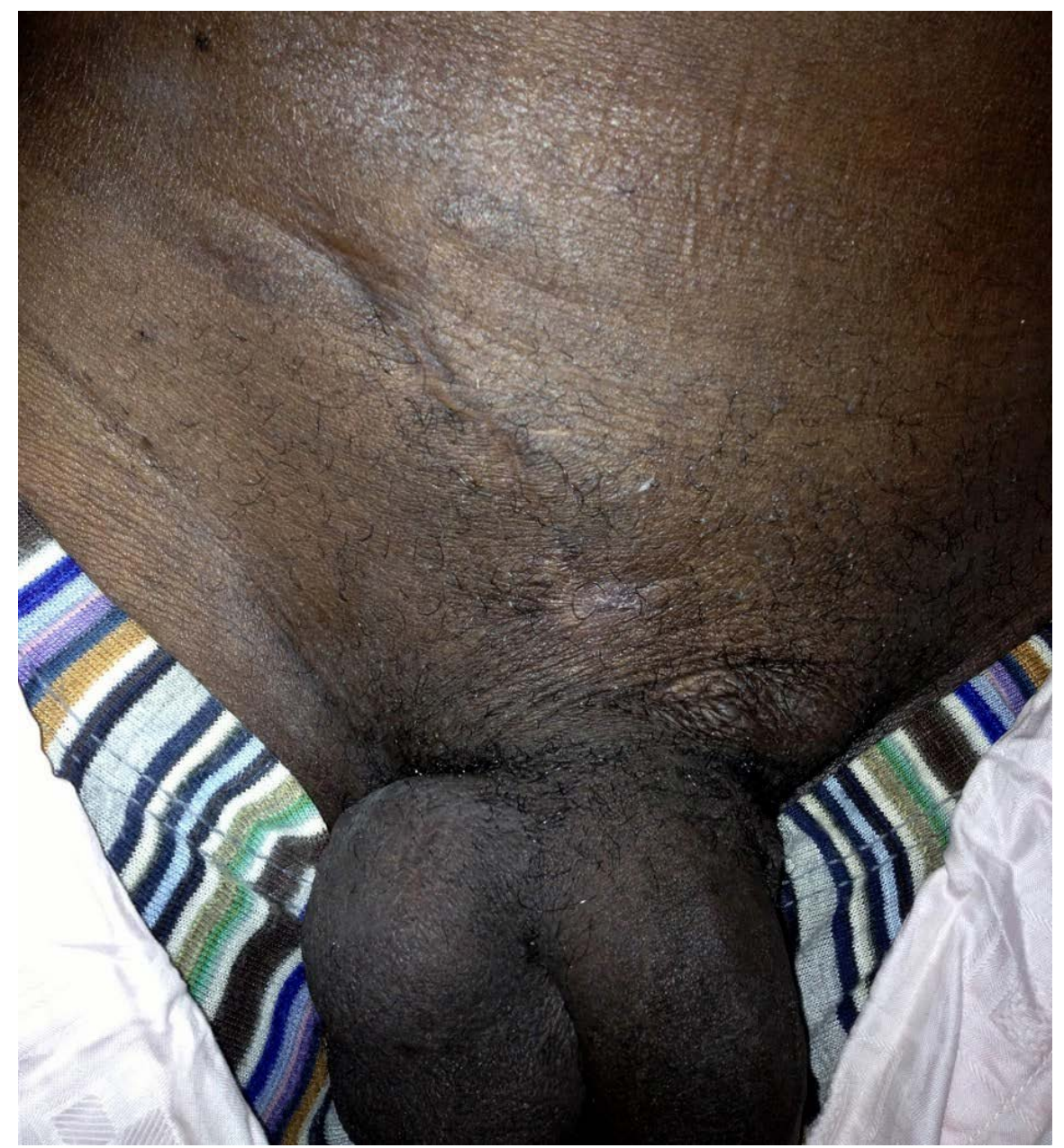

Figure 5. Postoperative result after 2 years.

differentiation of the extragonadal genital tract then the external genital organs. The presence of the testis in an ectopic scrotum defines the total ectopy of the scrotum. Like the malformation anomaly of the external general organs, it should be discovered by examining the newborn on the delivery bed or during the first consultations in pediatrics.

\subsection{Clinical Aspects}

The literature always emphasizes the risk of cancer and the hypofertility of the ectopic testis. The patient is the father of 8 children, despite the ectopic position of the testicle contained in an ectopic scrotum. Note that this ectopic testicle individualized in peroperative is of normal aspect. The extra-abdominal presence of the ectopic bursa (such as a diverticulum producing an abdominal skin addition image) undoubtedly confers on the testicle a normal temperature as if it were in a normal bursa (below the penis and perineum). We therefore understand that this patient is fertile and does not present any risk of cancer of his ectopic testicle despite his advanced age of 46 years. Testicular cancer is rare, accounting for $1 \%$ to $1.5 \%$ of the total human cancer and generally affects young 
people aged 15 - 35 years [6]. The intra abdominal localization of a testis is believed to be the cause of sterility, this being due to the fact that in an intra-abdominal position the testicle is subjected to a temperature of more than $37^{\circ} \mathrm{C}$, which would lead to a degradation of the seminiferous tubes, thus preventing spermatogenesis.

Cryptorchidism, testicular ectopy and penoscrotal transposition are the anomalies of the external genitalia well known to researchers as reported by multiple publications and benefit from a well-codified management today. The unilateral total ectopy of the scrotum that we describe is unusual since it is an ectopy of the scrotum and its contents. The lack of publication on this anomaly is evidence of its rarity. The evidence for the unilateral total ectopy of the scrotum comes from an analysis of a set of arguments below. The presence of a mass although of abdominopelvic seat, covered with a pleated skin and endowed with elasticity such as a scrotal skin in normal position. The absence of the medial raphe on the contralateral scrotum in normal position, with a testicle in a normal position. The intraoperative discovery of a testicle attached to the skin of the ectopic scrotal mass by the gubernaculum testis. Finally, the histological evidence of this scrotal skin is a further argument in favor of total scrotal ectopy. If all the elements concur in confirming the total unilateral ectopy of the scrotum, the challenge is to find an embryonic theory, given the enormous difficulties in finding a theory that is imposed on the others among the multiples that try to explain the frequent malformation anomalies (penoscrotal transposition, testicular ectopy).

\section{Conclusion}

The unilateral total ectopy of the right purse is a rare disease; its discovery is oriented by the symptomatology. The surgical treatment must, as far as possible, preserve the testicle.

\section{References}

[1] Kamina, P. (2014) Anatomie Clinique (Clinical Anatomy)-Scrotum. 3rd Edition, Edition Maloine de France, Paris, 306-307.

[2] Kamina, P. (2013). Périnée-Organes Génitaux Externes (Perineum-External Genitalia). Atlas d'Anatomie. Edition Maloine de France, Paris, 369-387.

[3] Elhaddad, N. and Elouahabi, H. (2016) Transposition pénoscrotale ou ambiguités sexuelles (Penoscrotal Transposition or Sexual Ambiguities: A Case Report): à propos d'un cas. Research, 3, 1554.

[4] Naren, S.D., Soren, C. and Subbarao, P.V. (2013) Penoscrotal Transposition: A Case Report. The Indian Journal of Surgery, 75, 64-65.

https://doi.org/10.1007/s12262-012-0472-1

[5] Iraqi, N., Gaouzi, A. and Bouhafs, M.A. (2010) Choix de sexe dans les dysgénésies gonadiques partielles XY (cas clinique) Sex of rearing in 46, XY partial gonadal dysgenesis (case report). Annales d'Endocrinologie, 71, 117-120.

https://doi.org/10.1016/j.ando.2009.11.008

[6] Niang, L., Diao, B., Gueye, S.M., Fall, P.A., Moby-Mpah, E.H., Jalloh, M., et al. 
(2007) Cancer sur testicule non descendu intra-abdominal. A propos de 5 cas (Cancer on Intra-Abdominal Testis Not Descended. 5 Cases Report). Progrès en Urologie, 17, 947-949. https://doi.org/10.1016/S1166-7087(07)92394-5

Submit or recommend next manuscript to SCIRP and we will provide best service for you:

Accepting pre-submission inquiries through Email, Facebook, LinkedIn, Twitter, etc. A wide selection of journals (inclusive of 9 subjects, more than 200 journals)

Providing 24-hour high-quality service

User-friendly online submission system

Fair and swift peer-review system

Efficient typesetting and proofreading procedure

Display of the result of downloads and visits, as well as the number of cited articles Maximum dissemination of your research work

Submit your manuscript at: http://papersubmission.scirp.org/

Or contact oju@scirp.org 